\title{
Pondering a Global BIPA: Politeness and Impoliteness in Verbal Interactions
}

\author{
Jumanto Jumanto \\ Universitas Dian Nuswantoro, Semarang, Indonesia \\ E-mail: ilhami@dsn.dinus.ac.id
}

\section{Emik Rahayu}

Universitas Dian Nuswantoro, Semarang, Indonesia

E-mail: emik.rahayu@dsn.dinus.ac.id

DOI: https://doi.org/10.18326/jopr.v2i2.97-112

Copyright (C) The Author (s)

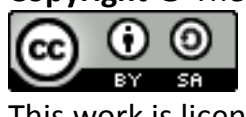

This work is licensed under a Creative Commons Attribution-ShareAlike 4.0 International License.

How to Cite: Jumanto, J., \& Rahayu, E. (2020). Pondering a Global BIPA: Politeness and Impoliteness in Verbal Interactions. Journal of Pragmatics Research, 2(2), 97-112. doi:https://doi.org/10.18326/jopr.v2i2.97-112

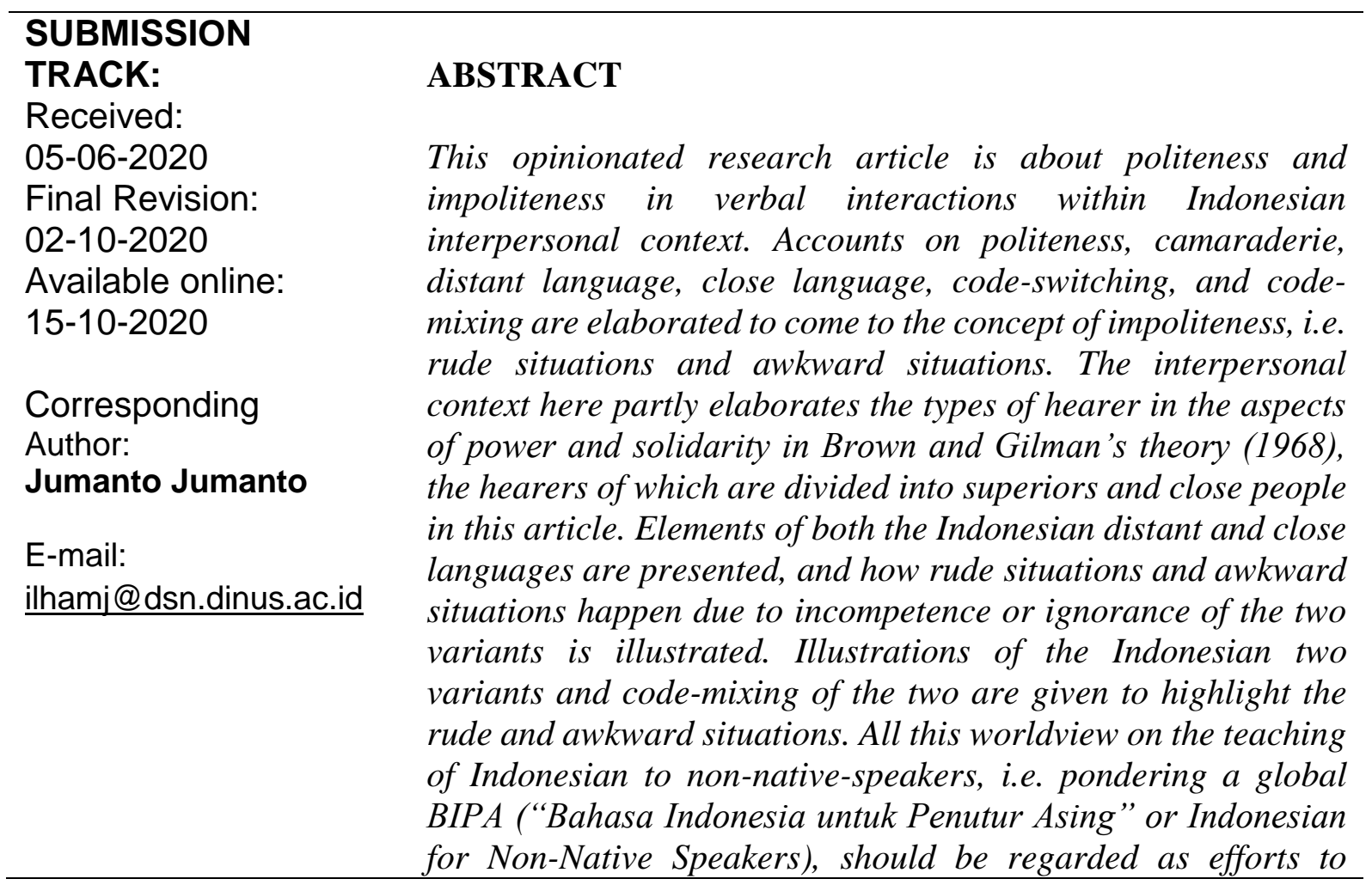


develop as well as to market the Indonesian language to the global societies.

Keywords Politeness, camaraderie, impoliteness, distant language, close language, rude situation, awkward situation, incompetence, code-switching, code-mixing, BIPA

\section{INTRODUCTION}

Bahasa Indonesia or the Indonesian language, or Indonesian, for short, is a developing language, and thus it is probable to adjust to the necessity or, probably better, demand, of the global users. This necessity or demand indeed invites innovation or invention, in the sense that global users may need to learn Indonesian from points of view of the world paradigms on linguistic development. In this context, Indonesian may adapt and adopt theories rampant in English whose development has been of contributions from linguists and researchers as well as practical users around the world.

Theories of politeness are one aspect to consider for elaborating language within social dynamics for verbal and non-verbal communications. As this politeness concerns interactions among people, some aspects of people in broad society, e.g. their power and solidarity, should be taken into account in the interactions. Here, types of hearer have come into play, as have been suggested in the grand theory of Brown and Gilman (1968), whether or not a hearer is superior, subordinate, close, not close, and equal. Types or variants of language are consequently elaborated according to this theory of types of hearer. This is for sure.

The teaching of Indonesian as a foreign language, or more notably termed as BIPA Indonesian for non-native speakers - has been carried out for years. In the writer's observation so far, the teaching has been more directed to random rules of the language, or else, to analyses on informal or formal corpora taken from everyday use of the language. Success or failure of that teaching is a matter of probability and relativity. Some teachers or researchers have claimed on the former, but others feel on the latter. The others are enthusiastic individuals who are striving or making best efforts to enhance the success of teaching BIPA, including all those who are present in the distinguished conference today, we should thank them for this. This endeavor is hopefully fruitful and will echoe the interest in and the charm of BIPA throughout the world for the increased importance and the better role of Indonesian among the world's dominant languages. Is this working? We do not know for sure yet. But something else probably needs to be done in this elaboration. This something else is what this article is trying to propose. 
Website: http://e-journal.iainsalatiga.ac.id/index.php/jopr/index

Pondering a global BIPA: politeness and impoliteness in verbal interactions is not a big proposition. Instead, this is just a trivial contribution to marketing Indonesian for the global users. This pondering involves theories of politeness, and more of recent proposal, concerns impoliteness, how rude and awkward situations are probable to happen based on their inappropriate forms of utterances and due to the speaker's incompetence or ignorance of the forms. Rude situations or awkward situations may happen in either situations of not close speakers or circumstances of close speakers. As the word impoliteness suggests, this notion has derived from the word politeness. Or, when politeness does not happen, impoliteness takes place. This article is highlighting the two concerns for better care and use by Indonesian people as well as foreign speakers trying to learn, speaking and writing Indonesian in their vast and various verbal interactions or communications.

\section{RESULT AND DISCUSSION}

\section{Issues on Formality, Informality, and Politeness}

Formality is something serious. Formality is 'when something or someone is serious and correct' (CALD, 2008: 562), or, another previous definition, 'formality refers to high or strict attention to rules, forms, and convention' (Hornby, 1987), or just 'attention to rules' (OLPD, 1983). Hence, formality suggests three aspects here, i.e. seriousness, correctness, and strict attention to rules, forms, and convention.

Heylighen and Dewaele (1999: 29), mentioning the findings of Tannen (1992), distinguish formality as 'report-talk' from informality as 'rapport-talk', which are the stylistic differences between men and women. They further explain that report-talk functions to present objective information to public, while rapport-talk is 'private speaking' and involves conversations among couples or small, intimate groups. In addition to this, a formal style will be characterized by detachment, precision, and 'objectivity', but also rigidity and cognitive load; an informal style will be much lighter in form, more flexible, direct, and involved, but correspondingly more subjective, less accurate and less informative (Heylighen and Dewaele, 1999: 33).

Politeness is something else serious. The word has derived from 'polite', i.e. (1) behaving in a way that is socially correct and shows understanding of and care for other people's feelings, (2) socially correct rather than friendly (CALD, 2008: 1095). From this sole source of definition, politeness suggests socially correct behaviors to show understanding of and care for 
other people's feelings. However, other people to consider here may fall into two categories, e.g. not close people and close people, or superiors and subordinates, as Brown and Gilman (1968) suggest. Does politeness have to do with formality? Does it have to do with seriousness, correctness, and strict attention to rules, forms, and convention? This is what the author is trying to elaborate in this article.

Issues on formality and politeness are interesting to bring up together, and that is why linguists and researchers around the world have made accounts on this relationship. Among others are worth discussing here below.

Formality and politeness have been frequently treated as equivalent (Sifianou, 2013: 88). However, formality is a multidimensional phenomenon and hard to define, largely because it subsumes many factors including familiarity, seriousness, and politeness (Trudgill, 1983; Pearce, 2005; in Sifianou, 2013: 88).

Concerning informality, we need to give special account on this. This concept is not easy to define in linguistics. A borrowing from the economy context, the term 'informal' was coined by Keith Hart in his article on informal income opportunities in Ghana, while the 1972 ILO report on employment and poverty in Kenya was the starting point of the subsequent notoriety of the 'informal sector' (Bangasser, 2000). In previous accounts, the concept of informality may refer to heterogeneity and inconsistencies, which is realized in terms of: non-observed, irregular, unofficial, second, hidden, shadow, parallel, subterranean, informal, cash economy, black market, unmeasured, unrecorded, untaxed, non-structured, petty production, and unorganized (Sindzingre, 2006: 5-2-3). In line with this, Kanbur (2009: 1) asserts that informality is a term that has the dubious distinction of combining maximum policy importance and political salience with minimal conceptual clarity and coherence in the analytical literature. Furthermore, Kanbur adds that the informality literature is vast and its multifaceted nature was "present at the creation" (2009: 1).

Heintz (2012: 3) also confirms on this issue of informality. He contends that it 'features prominently in development discourse, accompanied with a vast and growing literature; and in tandem with this, there are growing inconsistencies in the way it is conceptualized and measured' (2012: 3). Heintz proceeds that 'there is no single approach to defining informality and the definitions used in theoretical and empirical research often lack consistency from one 
Website: http://e-journal.iainsalatiga.ac.id/index.php/jopr/index

study to the next' (Guha-Khasnobis, Kanbur, and Ostrom, 2006; in Heintz, 2012: 5). Hence, however, from these few accounts, we would like to close that formality and informality exist in aspects of life, including aspects of language use.

\section{Politeness: From Face to Language Use}

From various theories of politeness (Leech, 1983), Brown and Levinson (1987), SpencerOatey (1992), Lakoff (1990), Fraser and Nolen (1981), Gu (1990), Ide (1989), Blum-Kulka (1992), Arndt and Janney (1985), Watts (1989), and Thomas' Pollyanna Hypothesis (1996) as have been explained by Jumanto (2014: II-337), the notion of face has come into important play in language use towards politeness and impoliteness. Jumanto provides a working definition of politeness below:

"Politeness is everything good that has been uttered as well as acted by the speaker to the hearer within a particular context, to maintain their interpersonal face as well as their social face" (2014: II-337).

Jumanto (2014), with his theory of distant language and close language, has asserted that language use is a matter of probabilities (2014: II-346). This assertion has been in line with the tendency of pragmatic viewpoints from Goffman's (1959) positive and negative face, Brown and Levinson's (1987) positive and negative politeness strategies, Renkema's (1993) solidarity and respect politeness, and Jumanto's (2006) friendship and politeness. This idea is not alone.

Another assertion has raised the similar theme. Politeness theory has primarily been investigated in face-to-face situations, with some exceptions (Herring, 1994; Sussman and Sproull, 1999; Morand and Ocker, 2003; Duthler, 2006). These exceptions, the author believes, are situation-based, e.g. in crowds in conference meeting breaks, when gossiping in public setting, in doctor-patient consultations, in personal consultations in newspapers or periodicals, or the most recent today, in computer-mediated communications. Some computer-mediated communications have been researched relevantly based on the hyperpersonal model by Walther (1996). However, utterances in real face-to-face situations are best referred to here in this article, as different forms of utterances can be created in such a way that they will suggest to either politeness or camaraderie. 
A clear highlight on politeness as elaboration of face into language use has been taken into account by Jumanto (2014: II-337), i.e. the presentation of distant language and close language. Distant language refers to distancing politeness to bring respect, while close language refers to closeness politeness to instill solidarity, the formula of which is stipulated in Table 1.

Table 1. Types of Language with their Types of Forms of Utterances (Jumanto, 2014: II-342)

\begin{tabular}{ll}
\hline Types of language & Types of forms of utterances \\
\hline $\begin{array}{l}\text { Distant Indonesian } \\
\text { language }\end{array}$ & $\begin{array}{l}\text { formal utterances, indirect utterances, non-literal } \\
\text { utterances }\end{array}$ \\
$\begin{array}{l}\text { Close Indonesian } \\
\text { language }\end{array}$ & $\begin{array}{l}\text { informal utterances, direct utterances, literal } \\
\text { utterances }\end{array}$ \\
\hline
\end{tabular}

Distant language is usually carefully elaborated and uses safe and common topics, while close language involves contractions, slangs, reverse-ups, changes, taboos, swearing, f-words, and uses any topics, personal and private (II-337). In his account for distant language and close language in the Indonesian context, Jumanto (2014) also explains that politeness is maintained when we use distant language and close language eligibly, i.e. to superiors or close people respectively. In this case the so-called code-switching for politeness happens, i.e. whether to use distant language or to use close language in a particular situation that may call. Illustrations have been given by Jumanto (2014) as follows:

\section{Politeness: using the distant Indonesian language to superiors}

(1) 'Semoga segera sembuh, Bapak Budi.'

'May you get better soon, Mister Budi.'

Topic: [well-being; health]

(2) 'Menurut saya, sebaiknya begini ....'

'I think that it is better like this ...'

Topic: [formal discussion at work]

(3) 'Maaf, Bapak. Saya ijin ke kamar kecil dulu.'

'Excuse me, Sir. May I go to the restroom, please?'

Topic: [permission; small-talk]

(4) 'Baik, Bapak. Saya akan segera memeriksanya lagi. Terima kasih.'

'Alright, Sir. I will check it out one more time. Thank you.' 
Topic: [workplace; jobs]

(5) 'Jika saya tidak salah, maaf, apakah Bapak tetangga baru kami yang dari Bandung itu?' 'If I am not mistaken, excuse me, are you our new neighbor from Bandung, Sir?' Topic: [neighborhood; small talk]

In the five utterances above, politeness is maintained, as the speakers are speaking to superiors by using a distant language, i.e. formal (1), indirect (2), non-literal (3), formal (4), and indirect (5) respectively. Topics covered in this talk are of distant language, i.e common and safe topics, e.g. health, work, jobs, neighborhood.

\section{Politeness: using the close Indonesian language to close people}

(1) 'Makasih banget bantuanmu, ya Sus!'

'Thanks so much for your help, OK, Sus!'

Topic: [personal loan to brothers/sisters/friends; others, close]

(2) 'Tolong hidupkan AC-nya!'

'Please turn on the AC!

Topic: [family or friends gathering]

(3) 'Ngapain kamu kok datang terlambat terus?'

'Why the hell d'you always come late?'

Topic: [hang-out appointment; friends gathering]

(4) 'Gimana kabarnya Susi? Sudah hamil lagi, katanya?'

'How's Susi doing? Rumors have, pregnant again?'

Topic: [gossiping; rumored pregnancy]

(5) 'Sialan! Aku pengin tinju saja orang itu!'

'Damn! Just wanna hit him in the face!'

Topic: [swearing; anger; solidarity]

In the five utterances above, politeness also happens. In this case, the speakers are speaking to close people by using a close language, i.e. informal (1), direct (2), literal (3), informal, direct (4), and direct, informal, literal (5) respectively. Topics covered in this talk are of close language, i.e any topics, personal and private, e.g. loan, gathering, pregnancy, swearing, anger. 


\section{Impoliteness: Rude Situations and Awkward Situations}

Politeness has been much talked about in this world of linguistics, and attention has then turned to the new variant, impoliteness. In the same sense, most research to date has focused on more straightforward instances of politeness, and more recently, impoliteness (Haugh and Culpeper, 2013). Interpersonal interactions can also involve mixed messages where features to point towards a polite interpretation are mixed with features to point towards an impolite interpretation (Rockwell, 2006; Culpeper, 2011). Social phenomena of politeness can also be analyzed as social actions or practices such as banter, teasing, jocular mockery, jocular abuse, ritual insults, sarcasm and the like, or as interpersonal evaluations such as mock impoliteness, mock politeness, insecure or manipulative politeness, pushy politeness, underpoliteness, overpoliteness, and so on (Haugh and Bousfield, 2012).

Not very apart from the politeness variants above, Jumanto (2014), in a simple model of politeness theory, stipulates that impoliteness in using the Indonesian language happens when we do not learn the distant language and the close language. When we use the close language to superiors, probably due to our lack of knowledge about distant Indonesian language, we are being not polite or we are being rude, or impoliteness happens (II-345).

On the other hand, when we use the distant language to close hearers, probably intentionally due to some interpersonal friction, we are also being not polite or impoliteness (or irony) happens (II-345). In this situation, we are trying to be distant to close hearers, and, therefore, awkwardness is in the air, and there is usually less harmony between us. In this theory by Jumanto (2014) there are two types of impoliteness. The former is called rude situations, the latter is called awkward situations.

\section{Impoliteness: rude situations}

This type of impoliteness, in Jumanto's model (2014), happens when we use the close language to superiors, thus rude situations entail. In this case, we use utterances which are informal, direct, and literal to people with bigger power. Informal utterances are incomplete, shorter forms, and are not in a good order, and sometimes cut-down, reversed-up, and changed in favor of the speaker (II-339). Examples in the Indonesian language are as follows:

(1) 'Cepet baikan, ya Pak Bud!' (?)

'Better soon, OK, Mr. Bud!' (?) 
Topic: [health wishes to superiors; not close]

(2) 'Saya tidak setuju dengan Anda.' (?)

'I do not agree with you.' (?)

Topic: [formal discussion at work with superiors]

(3) 'Maaf, Pak. Saya mau ke WC dulu.' (?)

'Excuse me, Sir. I want to go to the toilet first.' (?)

Topic: [permission to superiors]

(4) 'Bapak orang beragama? Apakah Bapak sering ke gereja?' (?)

'Are you religious? Do you often go to church?' (?)

Topic: [religion; personal affairs]

(5) 'Kenapa Anda sampai belum punya anak? 10 tahun perkawinan?'(?)

'Why don't you have any children? After 10 years of marriage?' (?)

Topic: [married without children; marriage]

Rude situations here happen in the five utterances above, as the speakers are speaking to superiors (usually not close) by using a close language. Here, (1) 'Cepet baikan, ya Pak Bud!' (informal), (2) 'Saya tidak setuju dengan Anda.' (direct), (3) 'Maaf, Pak. Saya mau ke WC dulu.' (literal), (4) 'Bapak orang beragama? Apakah Bapak sering ke gereja?' (direct), and 'Kenapa Anda sampai belum punya anak? 10 tahun perkawinan?' (informal, direct), respectively are of close language. Speaking to superiors like this, by using topics of close language, is potentially dangerous and is offensive. Topics like informal wishes (1), direct disagreements (2), literal private places (3), religion and personal affairs (4), and marriage (5) respectively, are personal and private, thus very touchy to be used to superiors. Impoliteness, in this sense, rude situations, inevitably happens.

\section{Impoliteness: awkward situations}

This type of impoliteness, also in Jumanto's model (2014), happens when we use the distant language to close people, thus awkward situations entail. In this case, we use utterances which are formal, indirect, and non-literal to people with solidarity. Formal utterances are complete, longer forms, and are in a good order (II-339). Examples in the Indonesian language are as follows:

(1) 'Saya mengucapkan terima kasih banyak atas bantuan Anda, ya Susanto!' (?) 
'I thank you very much for your help, OK, Susanto!' (?)

Topic: [personal loan to brothers/sisters/friends; others, close]

(2) 'Ruangannya kok panas, ya.' (?)

'It is hot here, isn't it.' (?)

Topic: [family or friends gathering]

(3) 'Wah, Anda pakai jam karet terus, nih!' (?)

'Well, you always have rubber time, don't you!' (?)

Topic: [hang-out appointment; friends gathering]

(4) 'Bagus banget, Anda tepat waktu lagi, ya. Pertemuan sudah hampir selesai.' (?)

'Very good. You are here on time again, Sir. The meeting is almost over.' (?)

Topic: [informal gathering; irony]

(5) 'Apakah Anda berkenan menunggu sebentar? (?)

'Would you mind waiting a minute, please?' (?)

Topic: [request; irony]

Awkward situations happen in the five utterances above, as the speakers are speaking to close hearers by using a distant language. Here, (1) 'Saya mengucapkan terima kasih banyak atas bantuan Anda, ya Susanto!' (formal), (2) 'Ruangannya kok panas, ya.' (indirect), (3) 'Wah, Anda pakai jam karet terus, nih!' (non-literal), (4) 'Bagus banget, Anda tepat waktu lagi, ya. Pertemuan sudah hampir selesai.' (formal, indirect), and (5) 'Apakah Anda berkenan menunggu sebentar?', respectively are of distant language. Talking to close people like this, by using topics of distant language, is distancing and awkward. Topics like formal thanking (1), indirect request (2), non-literal irony (3), formal, indirect irony (4), and indirect request (5) respectively, are distancing. The speakers are trying to be distant to close people; hence, impoliteness, in this sense, awkward situations, may happen.

\section{Code-Mixing for Politeness between Close People}

When code-switching, whether to use distant language or close language, is required for politeness as the situation calls, code-mixing between close people may also happen. Cases of confusion due to factors of power and solidarity (Brown and Gilman, 1968) may interfere verbal interactions between speakers and hearers. In the cases whether a superior is close or a close hearer has power, for example, code-mixing is sometimes used. However, code-mixing in language use, as the terminology suggests, belongs to informality. Thus, code-mixing between close people brings the close language, i.e. informal/formal, direct/indirect, and literal/non- 
literal utterances. In this case, use of language still instills solidarity, thus camaraderie is maintained. Jumanto (2014: II-346) has made illustrations on this confusion:

(1) 'Aku mengucapkan terima kasih banyak atas bantuanmu, ya Sus!'

'I thank you very much for your help, OK, Sus!'

Topic: [code-mixing for thanking]

(2) 'Saya tidak setuju dengan rencana kamu, lho!'

'I do not agree on your plan, you see.'

Topic: [code-mixing for disagreement]

(3) 'Wah, kamu ini pakai jam karet terus, sih!'

'Well, you always have rubber time, you know!'

Topic: [code-mixing for irony]

(4) 'Apakah Anda sudah dengar gosip terbaru? Tentang musuhmu itu,lho!'

'Have you heard the newest gossip, Sir? Well, about that someone you hate!'

Topic: [code-mixing for gossiping; partly joking]

(5) 'Menurut pendapat saya: Anda hebat sekali! Anda nampak macho seperti Sylvester Stallone!'

'I would like to say: that is very great of you, Sir! You look as macho as Sylvester Stallone!'

Topic: [code-mixing for giving compliments; partly joking]

Illustration (1) is a probable situation between a superior to a close subordinate, i.e. using a code-mixing of distant and close language. Here the expressions 'Aku', 'OK', 'Sus', and '-mu' are informal, while the expression 'mengucapkan terima kasih banyak atas bantuan-' is formal.

Meanwhile, illustration (2) is another probable situation between a subordinate to a close superior, i.e. using a code-mixing of distant language and close language. In this context, the expressions 'setuju', 'kamu', and 'lho' are informal, while the expressions 'saya' and 'tidak' are formal. The whole expression 'Saya tidak setuju dengan rencana kamu, lho.' itself is a direct utterance, thus used between close speakers.

The illustration (3) is also a probable situation between a superior to a close subordinate, i.e. using a code-mixing of distant and close language. Though the expressions 'wah', 'kamu', and 'sih' are informal (thus, part of close language), the expression 'jam karet' is non-literal, and thus, part of distant language. 
Another illustration (4) is a probable situation between a subordinate to a close superior, i.e. using a code-mixing of distant and close language. Though the expressions 'Apakah', 'Anda', and 'sudah' are formal (thus, part of distant language), the expressions 'dengar', '-mu', and 'lho' are informal, and thus part of close language.

The last illustration (5) is another probable situation between a subordinate to a close superior, i.e. using a code-mixing of distant and close language. Here the expressions 'Menurut pendapat saya' dan 'Anda' are formal (thus, part of distant language), while the expressions 'nampak' and 'macho' are informal, and thus, part of close language.

The five illustrations above show that as code-mixing happens only between close speakers, awkwardness does not usually happen, and solidarity politeness between them is maintained. Camaraderie instills, meaning that friendship is maintained between the close speakers

\section{CONCLUSION}

All the worldview on the teaching of Indonesian to non-native-speakers, i.e. pondering a global BIPA, should be regarded as efforts to develop as well as to market the Indonesian language for the global speakers. The worldview regards that language use depends on the types of hearer, i.e. superiors or close people, and on the types of politeness, whether to use distant language for respect politeness or to use close language for solidarity politeness. The codeswitching in language use in this case should be done eligibly. This way, politeness is maintained.

In cases of incompetence or ignorance in language use to a particular type of hearer, impoliteness may happen. This impoliteness leads to the so-called rude situations or awkward situations. The former happens as the result of using the close language to superiors, while the latter happens as the result of using the distant language to close people. In cases of confusion due to factors of power and solidarity in the hearer, code-mixing may happen. Code-mixing suggests informality, thus part of the close language. Between close speakers, code-mixing still brings politeness; however, between not close speakers, it may lead to impoliteness. 
Website: http://e-journal.iainsalatiga.ac.id/index.php/jopr/index

Pondering a global BIPA is indeed a set of efforts to apply theories of language use in the modern linguistic societies, where impoliteness, besides politeness which has enjoyed much contribution all over the world, has come into sufficient attention of ours. This way, BIPA teaching and learning process overseas is actually developing and potentially promising.

\section{ACKNOWLEDGEMENTS}

I would like to acknowledge all the distinguished people here for contributing their thoughts as well as precious opinions to the linguistic world I have academically lived in. The first group is nine English native speakers: (1) Samantha Custer (New England, US), John Custer (Pennsylvania, US), Bradford Sincock (Michigan, US), Patricia Mary O'Dwyer (South Ireland, GB), Patrick Bradley (Scotland, GB), Simon Colledge (London, UK, GB), Ian Briggs (Northern Territory, Australia), Anastasia de Guise (New South Wales, Australia), and Katrina Michelle Langford (Victoria, Australia). They have inspired me on how a linguist should perform in the linguistic world as well as on how I should learn more to observe people talking and to get real-life lessons for developing the pragmatic world.

I would also like to extend my gratitude to the second group of nine Indonesian professionals, Indonesian native speakers, without whom my linguistic world is not as enough as it is today: (1) Putri Mayangsari (freelance interpreter, Jakarta), Ria Herwandar (language consultant, Jakarta), Joseph Poerwono (company manager, Jakarta), Soetanto Hoetomo (school manager, Jakarta), Esther D. Tamtama (lecturer, Semarang), Herni Ambarwati (senior secretary, Semarang), Agus Sururi (hotel manager, Semarang), Didi Pribadi (restaurant manager, Semarang), and Siti Subiantari (liaison/guide, Jakarta).

Last but not least, I owe a lot to former linguists as well as researchers, whose works are both significant and helpful for making this article happen. May God the Almighty be with and bless them all. 


\section{REFERENCES}

Bangasser, P. E. (2000). The ILO and the Informal Sector: An Institutional History. Geneva: International Labour Office.

Blum-Kulka, S. (1992). The metapragmatics of Politeness in Israeli Society. In S. I. Richard Watts (Ed.), Politeness in Language: Studies in its History, Theory, and Practice. Berlin: Mouton de Gruyter.

Brown, P., \& Levinson, S. C. (1987). Politeness: Some Universals in Language Usage. New York: Cambridge University Press.

Brown, R., \& Gilman, A. (1968). The Pronouns of Power and Solidarity. In J. A. Fishman (Ed.), Readings in the Sociology of Language (pp. 252-275). The Hague: Mouton \& Co. N.V. Publishers.

CALD. (2008). Cambridge Advanced Learner's Dictionary, Third Edition. Cambridge: Cambridge University Press.

Culpeper, Jonathan (2011) Impoliteness: Using Language to Cause Offence. Cambridge: Cambridge University Press.

Duthler, Kirk W. 2006. The Politeness of Requests Made Via Email and Voicemail: Support for the Hyperpersonal Model, Journal of Computer-Mediated Communication (11), International Communication Association, doi: 10.1111/j.1083-6101.2006.00024.x, pp. 500-521.

Eelen, G. (2001). A Critique of Politeness Theories. Manchester: St. Jerome Publishing.

Fraser, B., \& Nolen, W. (1981). The Association of Deference with Linguistic Form.

International Journal of the Sociology of Language (27), 93-109.

Fries, C. C. (1979). Review of Grammatical analysis. In K. L. Pike, \& E. G. Pike, Language C. Fries. 1979. Review of Grammatical analysis, by Pike, Kenneth L. and Evelyn G. Pike. Language 55: 907-11. ed., pp. 907-11).

Goffman, E. (1959). The Presentation of Self in Everyday Life. New York: Anchor Books.

Gu, Y. (1990). Politeness Phenomena in Modern Chinese. Journal of Pragmatics , 14 , $237-$ 257.

Haugh, Michael, and Derek Bousfield (2012) Mock impoliteness, jocular mockery and jocular abuse in Australian and British English. Journal of Pragmatics44: 1099-1114. 
Website: http://e-journal.iainsalatiga.ac.id/index.php/jopr/index

Heintz, James. 2012. 'Informality, Inclusiveness, and Economic Growth: An Overview of Key Issues', SIG WORKING PAPER 2012/2. Amherst, USA: Political Economy Research Institute, University of Massachusetts, July 2012.

Heylighen, Francis and Dewaele, Jean-Marc. 1999. Formality of Language: Definition,

Measurement, and Behavioral Determinants, Internal Report, Center "Leo Apostel”. Brussels: Free University of Brussels.

Ide, S. (1989). Formal Forms and Dicernment: Two Neglected Aspects of Universals of Linguistic Politeness. Multilingua , 8 , 2-3; 223-248.

International Pragmatics Association, http://ipra.ua.ac.be, 13th International Pragmatics Conference, New Delhi, India , 8-13 September 2013

Jumanto. (2006). Phatic Communication among English Native Speakers (Komunikasi Fatis di Kalangan Penutur Jati Bahasa Inggris. An Unpublished Dissertation, University of Indonesia, Jakarta. Available at

http://www.lib.ui.ac.id/opac/themes/green/detail.jsp?id=92427

Jumanto (2014). 'Politeness and Camaraderie: How Types of Form Matter in Indonesian Context ; Proceding: The Second International Conference on Education and Language (2nd ICEL) 2014, pp. II-335 - II-350, Bandar Lampung University (UBL), Indonesia. http://artikel.ubl.ac.id/, ISSN: 2303-1417.

Kádár, D., and J. Culpeper (2010) Historical (im)politeness: An introduction. In J. Culpeper, and D. Kádár (eds.), Historical (Im)politeness. Bern/Oxford: Peter Lang, pp. 9-36.

Kanbur, Ravi. 2009. 'Conceptualising Informality: Regulation and Enforcement', at http://www.cornell.edu/pages/sk145, February, 2009.

OLPD. 1983. Oxford Learner's Pocket Dictionary. Oxford: Oxford University Press.

Renkema, J. (1993). Discourse Studies: An Introductory Textbook. Amsterdam: John Benjamins Publishing Company.

Rockwell, Patricia (2006) Sarcasm and Other Mixed Messages: The Ambiguous Ways People Use Language.Lewiston, N.Y.: Edwin Mellen Press.

Sifianou, Maria. 2013. The Impact of Globalisation on Politeness and Impoliteness, Journal of Pragmatics 55 (2013) 86-102.

Sindzingre, Alice. 2006. 'The Relevance of the Concepts of Formality and Informality: A Theoretical Appraisal' in Linking the Formal and Informal Economy: Concepts and 
Policies, Basudeb Guha-Khasnobies, Ravi Kanbur, and Elinor Ostrom eds. Oxford:

Oxford University Press, UNU-WIDER Studies in Development Economics and EGDI. Spencer-Oatey, H. (1992). Cross-Cultural Politeness: British and Chinese Conceptions of the

Tutor-Student Relationship.Unpublished PhD Thesis, Lancaster University, Lancaster.

Tannen, D. 1992. You just don't understand. Women and Men in Conversation. London: Virago Press.

Thomas, J. (1996). Meaning in Interaction: An Introduction to Pragmatics. London: Longman.

Walther, J.B. 1996. Computer-mediated communication: Impersonal, interpersonal, and hyperpersonal interaction. Communication Research, 23(1), 3-43.

Watts, R. (1989). Relevance and Relational Work: Linguistic Politeness as Politic Behavior.

Multilingua, 8 (2-3), 131-166. 